\title{
En åpenbar brist
}

Jeg foreslår at alle ledende helsemennesker som ikke fant opp kjernejournalen $f \varnothing r$ i september 2016, setter seg ned, gjerne med et glass vin, og går så grundig i seg selv at det gjør litt vondt.

Jeg har i alle år vært en frisk og tidvis til og med munter fyr som ikke oppsøker helsepersonell i utrengsmål. Jeg unngår leger hvis jeg kan. Det siste jeg ønsker, er en solbrun kjekkas som forteller meg at det dessverre ikke er noe som kan gjøres. Leger minner meg om ting jeg ikke ønsker å ha i livet mitt. Dere får meg, naturlig nok, til å tenke på sykdom og på død, og erfaringsmessig fungerer jeg bedre både kreativt og på andre måter når jeg slipper å tenke på disse tingene. For øvrig unngår jeg også tannleger, hvis det kan være noen trøst. De unngår jeg enda mer aktivt.

Det at noen er tiltrukket av legeyrket, kan jeg forstå. Det ligger i beste fall en edel komponent der et sted. Man helbreder, hjelper og trøster. Det er fine ting alt sammen. Motivasjonene for å bli tannlege er derimot usynlige for meg, og all kontakt med dem er ydmykende, smertefull og kostbar, så tannleger holder jeg meg unna til det gjør så vondt at jeg ikke klarer å tenke.

Her om året ble jeg likevel tvunget til å kontakte dere. Jeg hadde vært på Vestlandet med en av sønnene våre og kjøpt en bruktbil. Da vi kjørte hjemover, hadde jeg enormt vondt. Det hadde bygd seg opp over noen uker, men jeg hadde, som en idiot, latt som ingenting. Sønnen min og jeg holdt praten gående, og jeg forsøkte å late som om alt var i orden så han ikke skulle bli bekymret. Vi møtte resten av familien i Sverige, og jeg gikk rett til sengs, hvit i ansiktet. Kort etter ga jeg opp, ringte Helsetelefonen og fikk beskjed om å kontakte legevakten i Strömstad.

Mann, 44, med vondt i rumpa sent en lørdagsnatt. Jeg kunne se at de tenkte sitt.

Så undersøkte de meg og ble alvorlige i ansiktet. Det var en abscess, eller et helt system av abscesser. De kunne ikke gjøre noe der og da, så de ba meg dra videre, til Fredrikstad. Jeg kjørte videre, nå på smertestillende, ankom Fredrikstad og ble umiddelbart lagt i full narkose og operert.

Uken etter ble jeg operert igjen, denne gangen på Oslo universitetssykehus, Ullevål. De hadde ikke informasjon om at jeg uken før var blitt operert i Fredrikstad. Så begynte en rundgang mellom fastlege (alltid trivelig og hjelpsom), legevakt (ulike leger hver gang, som alle skar opp nye abscesser og ønsket lykke til videre - samtidig som de ikke hadde tilgang på informasjon fra de andre sykehusenel og Rikshospitalet (som heller ikke hadde tilgang på informasjon om hva de andre hadde gjort, ment eller sagt).

Jeg følte at jeg var blitt besatt av djevelen. Abscesser kom og gikk. Andre i familien fikk det også. Vi følte oss hjemsøkt, og i løpet av det neste halvannet året forsøkte det store, mangehodede Helsedyret å finne ut hva som kunne ligge bak. Det pussige var at prosessen begynte på nytt med hver person vi snakket med. Etter hvert forsto jeg at de ikke kommuniserte med hverandre, at det ikke fantes et sentralt arkiv hvor opplysningene ble delt.
De ante ikke hvilke prøver som var blitt tatt av andre, hvilke medisiner som var blitt brukt, eller når og hvor de andre hadde foretatt kirurgiske inngrep. Først trodde jeg ikke det kunne være mulig. Var dette Helse-Norge anno 2014? Hva hadde de i så fall drevet med i alle disse årene? Var det bare tøys og butikklek alt sammen?

Selv den grønneste amatør forstår vel at tilgang på en fullstendig sykdomshistorikk er avgjørende for å gi adekvat behandling. for å se om det finnes et helhetlig sykdomsbilde i for eksempel en familie. Og dessuten vil det redde liv. Men nei.

Hvis dette hadde vært i gamle dager, før dataalderen innhentet arkivene og myndighetenes mange systemer, hadde jeg ikke syntes det var noe pussig. Den gangen lå antagelig pasientinformasjon både i kjellere, på loft og i skuffer rundt omkring. Men dette er i dag. Det er 24 år siden jeg fikk min første e-postadresse, og leger har, så vidt jeg kan huske, tastet inn informasjon om oss nesten like lenge. Det er rett og slett ikke til å tro.

For et par uker siden fikk jeg en e-post hvor det med store, optimistiske bokstaver sto: «Til ERLEND LOE. Du mottar denne e-posten fordi Direktoratet for e-helse har opprettet en kjernejournal for deg...».

Det var ikke for tidlig. Lykke til videre med helsevesenet.

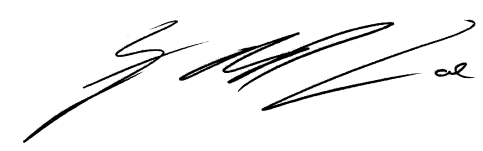

